\title{
Kualitas Ikan Cakalang (Katsuwonus pelamis) Presto pada Beberapa Hari Penyimpanan
}

\author{
Christiviany A. Lalompoha*, Feti Fatimaha, Johnly A. Roronga
}

aJurusan Kimia, FMIPA, Unsrat, Manado

\section{KATA K UNCI}

\section{Cakalang}

Presto

Pembumbuan

Daya simpan

\begin{tabular}{l}
$\overline{\text { K E Y W O R D S }}$ \\
\hline Cakalang \\
Presto \\
Seasoning \\
Storability
\end{tabular}

$\overline{\overline{\text { AVAILABLE ONLINE }}}$

A B S T R A K
Telah dilakukan penelitian tentang kualitas ikan Cakalang
(Katsuwonus pelamis) melalui proses presto pada beberapa hari
penyimpanan. Ikan presto merupakan ikan yang direbus pada suhu dan
tekanan tinggi sehingga menghasilkan ikan dengan duri yang lunak dan
mudah untuk dikonsumsi. Pengolahan ikan dilakukan dengan
menggunakan bumbu dan tanpa bumbu. Lama penyimpanan bergantung
pada kerusakan ikan. Kualitas ikan yang diukur adalah kadar protein,
kadar air, kadar malondialdehid (MDA), dan Total Plate Count (TPC). Hasil
penelitian menunjukkan bahwa kadar protein ikan cakalang presto pada
semua perlakuan, mengalami peningkatan setelah melalui proses presto.
Kadar air dan nilai TPC pada semua perlakuan dan kadar MDA pada
pemberian bumbu, belum melewati batas mutu, sedangkan kadar MDA
ikan Cakalang presto tanpa pemberian bumbu, sudah melewati batas
mutu yang ada.
A B S T R A C T
Studies about the quality of Cakalang fish (Katsuwonus pelamis)
through presto process on several days storage has been carried out.
Presto fish is a fish boiled at high temperature and pressure to produces
spines fish that soft and easily consumed. Fish processed by using
seasoning and without seasoning. The storage time depends on the
desstruction of fish. Fish quality that measured are protein content, water
content, malondialdehid (MDA) content, and Total Plate Count (TPC). The
results showed that the protein content of Cakalang presto of all
treatmens increased through the presto process. Water content and TPC
value of all treatments and MDA content of seasoning treatment yet to
pass the quality line, while MDA content of Cakalang presto without
seasoning treatment has passed the existing quality line.

\section{Pendahuluan}

Indonesia merupakan salah satu negara kepulauan yang dikelilingi laut yang cukup luas, sehingga banyak masyarakat Indonesia memanfaatkan laut sebagai lahan pekerjaan atau sebagai sumber pangan yang berasal dari ikan dan hasil laut lainnya. Pengembangan produksi perikanan dapat dilakukan karena ikan memiliki kandungan gizi yang baik, yang dapat bermanfaat bagi manusia. Selain protein yang tersusun atas asam amino yang lengkap, ikan juga mengandung lemak yang sebagian besar tersusun oleh asam lemak tak jenuh omega-3, yang dapat bermanfaat bagi kesehatan dan perkembangan otak (Irianto dan Soesilo, 2007).

Ikan memiliki berbagai macam manfaat, namun ikan juga termasuk komoditas yang cepat mengalami kerusakan. Kerusakan pada ikan dapat disebabkan karena kandungan air dan protein yang relatif tinggi sehingga menjadi media yang baik bagi pertumbuhan bakteri dan jamur yang menyebabkan kerusakan pada ikan (Heruwati, 2002). Untuk itu, sebaiknya setelah proses penangkapan, ikan yang dihasilkan harus segera diolah.

Salah satu teknik pengolahan ikan yang bisa dilakukan adalah pemindangan. Namun produk dari

*Corresponding author: Jurusan Kimia FMIPA UNSRAT, Jl. Kampus Unsrat, Manado, Indonesia 95115; Email address: chlalompoh@gmail.com

Published by FMIPA UNSRAT (2015) 
teknik ini masih menimbulkan kendala pada saat dikonsumsi karena pengolahan tersebut hanya mempengaruhi komposisi daging, rasa, dan tekstur ikan, tetapi tidak dapat melunakkan tulang dari ikan tersebut. Oleh karena itu sekarang telah berkembang teknologi pindang duri lunak atau presto ikan. Menurut Tapotubun et al. (2008), presto ikan merupakan pengolahan ikan melalui proses pemanasan pada tekanan tinggi dengan penambahan garam dan bumbu, menghasilkan ikan dengan duri yang lunak sehingga bisa dikonsumsi secara langsung dengan durinya. Ikan presto merupakan salah satu produk pangan yang telah banyak dipasarkan, sehingga perlu dilakukan pengujian untuk mengetahui kualitas ikan yang dihasilkan dari proses presto. Tujuan penelitian ini adalah menguji kualitas ikan Cakalang (Katsuwonus pelamis) presto dengan menggunakan bumbu dan tanpa bumbu, pada beberapa hari penyimpanan.

\section{Metode}

\subsection{Bahan dan Alat}

Sampel yang digunakan adalah ikan cakalang segar yang diperoleh dari pelelangan ikan Tumumpa Manado, bumbu-bumbu masakan yang diperoleh dari pasar tradisional Bersehati Manado, aquades, selenium, asam sulfat pekat, natrium klorida 0,9\%, natrium hidroksida $0,1 \mathrm{~N}$, asam klorida $0,01 \mathrm{~N}$, asam borat, Phenoftalein (PP), asam trikloroasetat (TCA) $10 \%$, asam tiobarbiturat (TBA) 1\%, Plate Count Agar (PCA). Semua bahan yang digunakan adalah analytical grade.

Peralatan yang digunakan dalam penelitian ini adalah panci presto, lemari pendingin, cawan porselin, sentrifus, waterbath, labu Kjeldahl, seperangkat alat titrasi, alat pemanas (oven), desikator, autoclave, inkubator, dan spektrofotometer UV-Vis.

\subsection{Pembuatan Ikan Cakalang Presto}

Ikan Cakalang disiangi, dicuci, dan ditimbang. Selanjutnya dibuat dalam dua perlakuan. Perlakuan pertama yaitu ikan cakalang segar tanpa pemberian bumbu, dan perlakuan kedua dengan pemberian bumbu. Ikan yang dibuat dengan pemberian bumbu direndam dengan larutan garam 3\% selama 15 menit lalu dicuci dan ditiriskan. Setelah itu direndam lagi dalam larutan garam jenuh (20\%) selama 15 menit kemudian dilaburi bumbu yang telah dihaluskan (bawang merah 4,4\%, bawang putih 0,5\%, cabe 0,5\%, kemiri 4,4\%, lengkuas $0,5 \%$, bahan penyedap masakan 0,3\%, daun salam, sereh, dan asam jawa). Selanjutnya ikan yang tidak dibumbui dan ikan yang dibumbui direbus dalam panci presto dengan air sebanyak 1 liter selama 90 menit. Tahap berikutnya, ikan disimpan di tempat sampel uji selama 3 hari pada suhu $5^{\circ} \mathrm{C}$. Masing-masing sampel ikan dari 2 perlakuan kemudian diuji karakteristiknya secara berkala meliputi uji kadar protein, kadar air, kadar MDA, dan TPC.

\subsection{Uji Kadar Protein dengan Metode Makro Kjeldahl}

Ditimbang 0,5 g sampel dan dimasukkan ke dalam labu Kjeldahl $100 \mathrm{ml}$. Selanjutnya ditambahkan dengan campuran 2 g selenium dan 25 $\mathrm{ml}$ asam sulfat pekat. Didestruksi sampai larutan menjadi hijau jernih. Tahap selanjutnya, larutan hijau jernih didinginkan, diencerkan, dan dimasukkan ke dalam labu ukur $100 \mathrm{ml}$. Dipipet $5 \mathrm{ml}$ larutan dan dimasukkan ke dalam alat penyulingan dan ditambahkan $5 \mathrm{ml}$ natrium hidroksida 30\% dan beberapa tetes indikator PP. Selanjutnya disuling selama 10 menit dan ditampung pada $10 \mathrm{ml}$ larutan asam borat $2 \%$ yang telah dicampur dengan indikator PP. Selanjutnya dititrasi dengan asam klorida 0,01 N, dan dibuat blanko. Dihitung kadar proteinnya.

\subsection{Uji Kadar Air dengan Metode Oven}

Cawan kosong dikeringkan dalam oven dengan suhu $105^{\circ} \mathrm{C}$ selama 60 menit. Selanjutnya cawan tersebut didiginkan dalam desikator selama 30 menit. Sebanyak 5 gram sampel dimasukkan ke dalam cawan, ditimbang, dan ditempatkan di dalam oven dengan suhu $105^{\circ} \mathrm{C}$, selama 3 jam. Tahap selanjutnya, cawan dipindahkan ke desikator, didinginkan, dan ditimbang. Dihitung kadar airnya.

\subsection{Analisis Kadar MDA dengan Metode Thiobarbituric Acid Reactive Substance (TBARS)}

Sebanyak 0,5 g sampel dimasukkan dalam tabung reaksi dan ditambahkan $4 \mathrm{ml}$ asam trikloroasetat (TCA) 10\%. Selanjutnya disentrifus selama 10 menit, kemudian diambil supernatant dan ditambahkan dengan 2,5 ml asam tiobarbiturat (TBA) 1\%. Tahap selanjutnya, larutan dicampur sampai homogen dengan dipanaskan dalam waterbath selama 10 menit lalu didinginkan. Diukur absorbansi filtrat yang berwarna merah muda pada panjang gelombang $532 \mathrm{~nm}$ dengan menggunakan spektrofotometer UV-Vis. Kadar MDA dihitung dengan menggunakan kurva baku standar dari tetraetoksipropana (TEP) sebagai prekursor MDA.

\subsection{Uji TPC}

Alat dan bahan yang akan digunakan sepereti Erlenmeyer, botol serum, pipet mikro, dan media agar, disterilisasi dalam autoclave selama 15 menit. Media yang digunakan adalah PCA (Plate Count Agar). Suspensi contoh dilakukan dengan pengenceran $10^{-1}$ dengan menghancurkan 1 gram sampel ke dalam 9 $\mathrm{ml}$ larutan pengencer ( $\mathrm{NaCl} 0,9 \%)$. Suspensi bahan 1 $\mathrm{ml}$ dimasukkan ke dalam $9 \mathrm{ml}$ larutan pengencer untuk mendapatkan pengenceran yang diinginkan. Suspensi yang telah ada dicampurkan dengan media agar, kemudian koloni bakteri dihitung setelah inkubasi selama 2 hari pada suhu $30^{\circ} \mathrm{C}$. Jumlah koloni yang diterima 25-250 koloni per cawan. Dihitung nilai TPC.

\section{Hasil dan Pembahasan}

\subsection{Kadar Protein}

Kadar protein pada ikan cakalang presto dapat dilihat pada Gambar 1. 
Berdasarkan data pada Gambar 1, penambahan bumbu pada pengolahan ikan presto memberikan pengaruh terhadap kadar protein dari ikan yang dihasilkan. Ikan cakalang presto yang diolah dengan penambahan bumbu memiliki kandungan protein yang lebih rendah dibanding ikan cakalang presto yang diolah tandpa penambahan bumbu. Hal ini disebabkan karena adanya penambahan garam pada proses pembumbuan. Seperti yang telah disebutkan oleh Heruwati (2002), bahwa penurunan kadar protein pada ikan bergantung pada kadar garam dan waktu penggaraman. Afrianto dan Liviawaty (2005) juga mengemukakan bahwa pada tubuh ikan terdapat protein globular yang merupakan protein yang mudah larut dalam air dan larutan garam. Selain itu, konsentrasi garam dapat menyebabkan terdenaturasinya protein pada tubuh ikan.

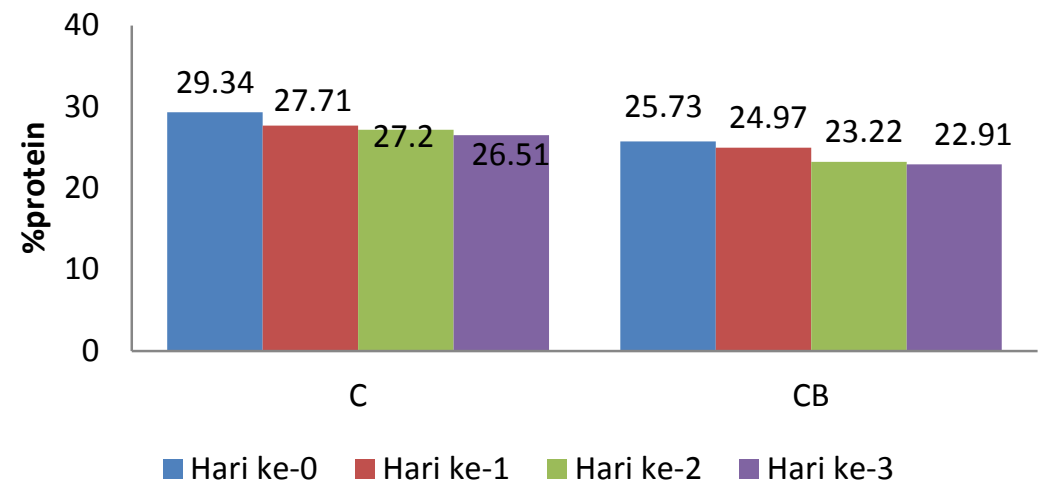

Gambar 1 - Kadar protein ikan cakalang presto $(C=$ Cakalang presto tanpa bumbu; $\mathrm{CB}=$ Cakalang presto yang dibumbui)

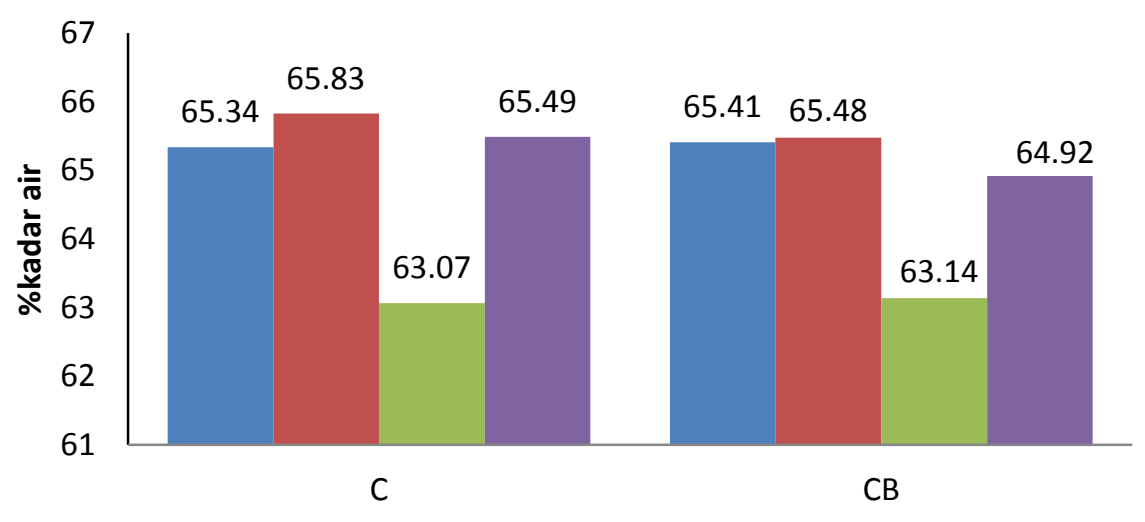

Hari ke-0 Hari ke-1 Hari ke-2 $\quad$ Hari ke-3

\section{Gambar 2 - Kadar air ikan cakalang presto ( $\mathrm{C}=$ Cakalang presto tanpa bumbu; $\mathrm{CB}=$ Cakalang presto yang dibumbui)}

Jika ditinjau dari lama penyimpanan yang dilakukan sampai hari ke-3, kadar protein mengalalmi kecenderungan menurun, tetapi menurut Khodabux et al. (2007), kadar protein ikan cakalang segar atau tanpa pengolahan berkisar antara 21,80$25,10 \%$ oleh karena itu maka kadar protein ikan cakalang presto, baik yang diolah tanpa proses pembumbuan atau melalui proses pembumbuan dalam penelitian ini masih lebih tinggi, yaitu berkisar antara 22,91 - 29,34\%. Hal ini disebabkan karena pengolahan ikan presto dilakukan dengan menggunakan garam dan suhu tinggi. Menurut Tapotubun et al. (2008), pengolahan dengan menggunakan garam dan suhu tinggi dapat menyebabkan terjadinya pengeluaran air dari daging ikan sehingga protein yang terkandung pada daging ikan akan lebih terkonsentrasi. Hal ini sependapat dengan Suharjo (1998), garam selain sebagai penyedap masakan, juga dapat menurunkan kadar air, sehingga protein akan lebih terkonsentrasi.

\subsection{Kadar Air}

Kadar air dari ikan cakalang presto dapat dilihat pada Gambar 2.

Berdasarkan Gambar 2, dapat dilihat bahwa ikan cakalang presto yang diolah dengan menggunakan bumbu atau tanpa penggunaan bumbu, menunjukkan nilai yang tidak jauh berbeda. Salah satu bumbu yang digunakan adalah bawang putih. Berdasarkan penelitian yang telah dilakukan oleh Putro et al. 
(2008), terbukti bahwa ekstrak bawang putih tidak mempengaruhi kadar air ikan.

Jika ditinjau dari lama penyimpanan, kadar air ikan cakalang presto pada semua perlakuan, tidak mengalami perubahan sampai pada penyimpanan hari ke-1, namun pada penyimpanan hari ke-2 terjadi penurunan kadar air. Hal ini disebabkan oleh lingkungan tempat penyimpanan yang memungkinkan terjadinya penurunan kadar air. Pada suhu rendah, jaringan protein tidak dapat lagi mengikat air yang menyebabkan berkurangnya kadar air pada ikan. Menurut Rospiati (2006), penyimpanan pada suhu rendah menyebabkan lemahnya sistem ikatan hidrogen, sehingga terjadi aggregasi protein dan jaringan protein tidak dapat lagi mengikat air.
Sedangkan pada penyimpanan hari ke-3, kadar air dari produk presto mengalami peningkatan. Menurut Kaparang et al. (2013), meningkatnya kadar air ikan pada proses penyimpanan disebabkan karena produk dapat menyerap air dari lingkungan. Kadar air ikan cakalang presto dari semua perlakuan dan penyimpanan sampai hari ke-3 belum melewati batas mutu yang ada. Standar mutu kadar air untuk produk perikanan adalah 60 - 70\% (Arpah, 1993).

\subsection{Analisis Kadar MDA dengan Metode Thiobarbituric Acid Reactive Substance (TBARS)}

Kadar MDA yang diperoleh dari penelitian dapat dilihat pada Gambar 3.

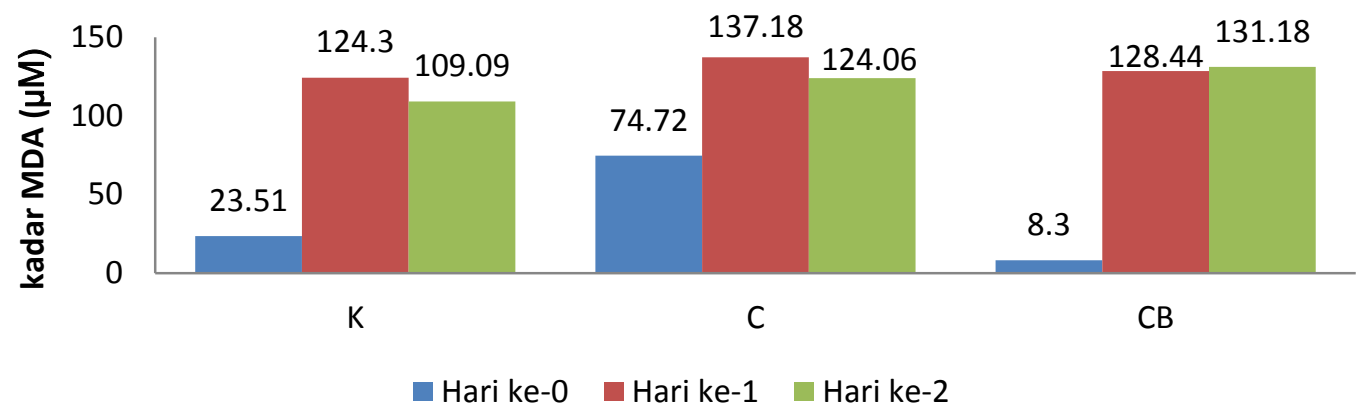

Gambar 3 - Kadar MDA ikan cakalang presto ( $\mathrm{K}=$ Kontrol; $\mathrm{C}=$ Cakalang presto tanpa bumbu; $\mathrm{CB}=\mathrm{Cakalang}$ presto yang dibumbui)

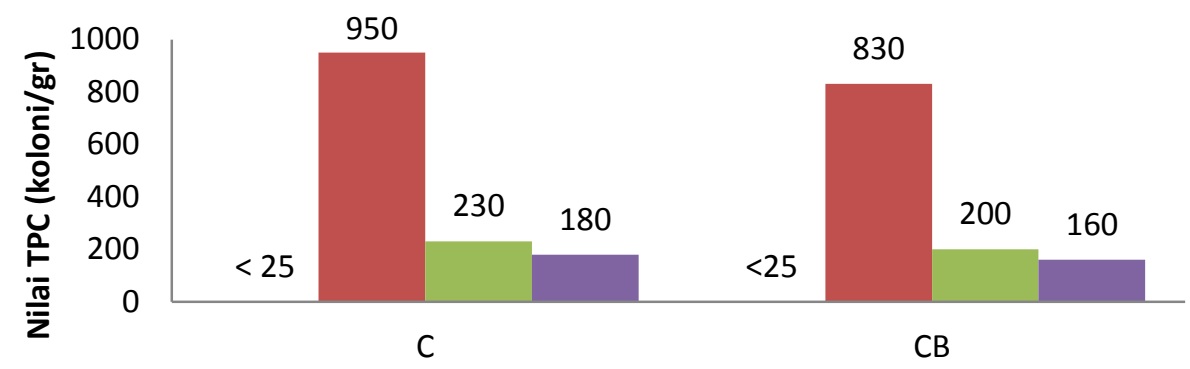

Hari ke-0 $\quad$ Hari ke-1 Hari ke-2 $\quad$ Hari ke-3

\section{Gambar 4 - Nilai TPC ikan cakalang presto $(C=$ Cakalang presto tanpa bumbu; $\mathrm{CB}=$ Cakalang presto yang dibumbui)}

Berdasarkan Gambar. 3, dapat dilihat bahwa kadar MDA untuk ikan cakalang presto menunjukkan nilai yang rendah pada hari ke-O. Kadar MDA untuk ikan cakalang presto yang diolah dengan menggunakan bumbu menunjukkan nilai terendah dibandingkan dengan kontrol, dan ikan cakalang presto yang diolah tanpa pembumbuan. Hal ini menunjukkan bahwa bumbu yang digunakan dapat berpengaruh pada produk presto yang dihasilkan. Bumbu-bumbu yang digunakan pada pengolahan ikan presto memiliki kemampuan antioksidan yang dapat menghambat terjadinya oksidasi lemak. Cabai dan lengkuas merupakan bumbu masak yang telah terbukti mengandung senyawa antioksidan (Cahyono, 2013; Utami et al., 2013). Kadar MDA ikan cakalang presto yang diolah dengan penambahan bumbu belum melewati batas mutu yang ada, sedangkan kadar MDA ikan cakalang presto yang diolah tanpa penambahan bumbu sudah melewati batas mutu yang ada. Batas mutu ikan dengan uji TBA adalah 10 $\mu \mathrm{M}$ (Ke dan Ackman, 1976).

Seiring bertambahnya waktu penyimpanan, kadar MDA ikan cakalang presto untuk semua perlakuan mengalamai peningkatan. Hal ini menunjukkan bahwa semakin lama waktu penyimpanan, semakin banyak reaksi oksidasi yang terjadi. Penelitian yang dilakukan oleh Wijayanti et al. (2006), menunjukkan ikan cakalang yang disimpan pada suhu rendah hingga hari ke-3, mengalami proses oksidasi yang lebih tinggi dibanding proses reduksi. Sohn et al. (2005), juga mengungkapkan 
bahwa asam lemak tak jenuh yang terdapat pada ikan biasanya teroksidasi pada awal penyimpanan.

\subsection{Total Plate Count (TPC)}

Nilai TPC yang diperoleh dari dapat dilihat pada Gambar 4.

Berdasarkan Gambar. 4, dapat dilihat bahwa pada hari ke-0, ikan cakalang presto yang diolah baik melalui proses pembumbuan ataupun tidak, menunjukkan nilai TPC yang rendah, yaitu $<25$ koloni/gram. Hal ini disebabkan karena pada proses presto digunakan suhu tinggi yang dapat menyebabkan kematian pada sel bakteri. Selain itu, waktu pemanasan juga berpengaruh pada jumlah bakteri yang dihasilkan dari proses presto. Penelitian yang dilakukan oleh Tapotubun et al. (2008), menunjukkan semakin lama waktu pemanasan, jumlah bakteri yang terdapat pada hasil presto semakin sedikit. Hal ini disebabkan karena semakin lama waktu pemanasan, daya tahan bakteri terhadap panas akan hilang dan menyebabkan kematian.

Penggunaan bumbu juga dapat berpengaruh pada nilai TPC yang dihasilkan dari ikan cakalang presto. Berdasarkan hasil yang diperoleh, ikan cakalang presto yang diolah dengan menggunakan bumbu memiliki nilai TPC yang lebih rendah dari ikan cakalang presto yang diolah tanpa penambahan bumbu. Hal ini disebabkan karena pada proses pembumbuan, terdapat garam yang memilki kemampuan untuk membunuh bakteri. Menurut Muchidien dan Hardhy (1985), garam dapat membunuh jasad renik serta peka terhadap $\mathrm{CO}_{2}$. Selain itu, bumbu-bumbu yang digunakan seperti bawang merah, bawang putih, lengkuas, daun salam, sereh, dan asam jawa juga mengandung senyawa antibakteri yang dapat menghambat pertumbuhan bakteri pada ikan. Penelitian yang dilakukan oleh Rahayu (2000), menunjukkan bumbu masakkan dapat menghambat pertumbuhan bakteri pada makanan.

Jika ditinjau dari lama penyimpanan, nilai TPC pada semua perlakuan mengalami penurunan. Hal ini disebabkan karena suhu penyimpanan yang rendah. Menurut Gelman et al. (2001), pada suhu $2^{0}-10^{\circ} \mathrm{C}$, bakteri mengalami pertumbuhan yang lambat sehingga mutu ikan menurun dengan lambat dan daya simpannya lebih lama. Suhu rendah juga menyebabkan proses-proses biokimia yang terjadi pada tubuh ikan menjadi lebih lambat. Nilai TPC ikan cakalang presto dari semua perlakuan belum melewati batas mutu hingga penyimpanan hari ke-3. Berdasarkan Standar Nasiolan Indonesia, batas maksimum jumlah koloni bakteri untuk ikan segar dan ikan olahan adalah $5 \times 10^{5}$ koloni/gram.

\section{Kesimpulan}

Ikan cakalang presto yang diolah dengan penambahan bumbu dan tanpa penambahan bumbu menunjukkan kualitas yang cukup baik. Kadar protein ikan cakalang presto mengalami peningkatan setelah melalui proses presto. Kadar air dan nilai TPC pada semua perlakuan dan kadar MDA pada pemberian bumbu, belum melewati batas mutu, sedangkan kadar MDA ikan cakalang presto tanpa pemberian bumbu, sudah melewati batas mutu yang ada.

\section{Daftar Pustaka}

Afrianto, E., dan Liviawaty, E. 2005. Pakan Ikan. Kanisius, Yogyakarta.

Arpah, M. 1993. Pengawasan Mutu Pangan. Penerbit Tarsito, Bandung.

Cahyono, B. 2013. Cabai Rawit. Kanisius, Yogyakarta.

Gelman, A., L. Glatman, V. Drabkin, dan S. Harpaz. 2001. Effect of Storage Temperature and Preservative Treatment on Shelf Life of The Pondraised Freshwater Fish, Silver Perch (Bidyanus bidyanus). Journal Food Protection. 64 : 15841591.

Heruwati, E. S. 2002. Pengolahan Ikan Secara Tradisional: Prospek dan Peluang Pengembangan. Jurnal Litbang Pertanian. 21 : 92-99.

Irianto, H. E., dan I. Soesilo. 2007. Dukungan Teknologi Penyediaan Produk Perikanan. Makalah pada Seminar Nasional Hari Pangan Sedunia. Badan Riset Kelautan dan Perikanan, Departemen Kelautan dan Perikanan, Bogor.

Kaparang, R., S. D. Harikedua, dan I K. Suwetja. 2013. Penentuan Mutu Ikan Tandipang (Dussumieria acuta C.V) Asap Kering Selama Penyimpanan Suhu Kamar. Jurnal Media Teknologi Hasil Perikanan. 1 : 1-6.

Ke, P. J., dan R. G. Ackman. 1976. Metal-catalysed Oxidation in Mackerel Skin and Meat Lipids. J. Am. Oil Chem. Soc. 53 : 636-640.

Khodabux, K., M. S. S. L'Omelette, S. JhaumeerLaulloo, P. Ramasami, dan P. Rondeau. 2007. Chemical and Near-Infrared Determination of Moisture, Fat and Protein in Tuna Fishes. Food Chem.102 : 669-675.

Muchidien, A., dan L. T. Hardhy. 1985. Ikan Pindang. PT. Widya Karya Pratama, Jakarta.

Putro, S., Dwiyitno, J. F. Hidayat, dan M. Pandjaitan. 2008. Aplikasi Ekstrak Bawang Putih (Alium sativum) untuk Memperpanjang Daya Simpan Ikan Kembung Segar (Rastrelliger kanagurta). Jurnal Pascapanen dan Bioteknologi Kelautan dan Perikanan. 3 : 193-200.

Rahayu, W. P. 2000. Aktifitas Antimikroba Bumbu Masakana Tradisional Hasil Olahan Industri terhadap Bakteri Patogen dan Perusak. Bul. Teknol. dan Industri Pangan. 11 : 42-48.

Rospiati, E. 2006. Evaluasi Mutu dan Nilai Gizi Nugget Daging Merah Ikan Tuna (Thunnus sp) yang Diberi Perlakuan Titanium Dioksida. Sekolah Pascasarjana ITB, Bogor.

Sohn, J. H., Y. Taki, H. Ushio, T. Kohata, dan T. Ohshima. 2005. Lipid Oxidation in Ordinary and 
Dark Muscles of Fish: Influences on Rancid Offodor Development and Color Darkening of Yellowtail Flesh During Ice Storage. Journal of Food Science. $70:$ 490-496.

Suharjo. 1998. Pangan, Gizi dan Pertanian. UI Press, Jakarta.

Tapotubun, A. M., E. E. E. M. Nanlohy, dan J. M. Louhenapessy. 2008. Efek Waktu Pemanasan terhadap Mutu Presto Beberapa Jenis Ikan. Ichthyos. $7: 65-70$.
Utami, R., Kawiji, E. Nurhartadi, M. Kurniasih, dan D. Indianto. 2013. Pengaruh Minyak Atsiri Jahe Merah dan Lengkuas Merah pada Edible Coating terhadap Kualitas Fillet Ikan Patin. Agritech. 33 : 1-18.

Wijayanti, I., F. Swastawati, dan T. W. Agustini. 2006. Pola Perubahan K-Value dan ORP Ikan Cakalang (Katsuwo pelamis) pada Penyimpanan Suhu Rendah $\left( \pm 11^{\circ} \mathrm{C}\right)$. Jurnal Pasir Laut. 3: 1-12. 